\title{
VALIDATION OF THE SOCIAL ENTREPRENEURIAL ANTECEDENTS SCALE IN UNIVERSITY STUDENTS IN MEXICO
}

\author{
Francisco Quiñonez Tapia \\ University of Guadalajara, Guadalajara, Jalisco, México \\ Email: fcoqtapia@cucea.udg.mx \\ Fabiola González-Betanzos \\ Michoacan University of San Nicolas de Hidalgo Morelia, Michoacán, México \\ Email: fbetanzos@umich.mx \\ María de Lourdes Vargas-Garduño \\ Michoacan University of San Nicolas de Hidalgo Morelia, Michoacán, México \\ Email: mlvargas@umich.mx \\ Zarina Estela Aguirre Lozano \\ University of Guadalajara, Guadalajara, Jalisco, México \\ Email: zarinaaguirre@,cucea.udg.mx
}

Received: 19 February 2020. Revision received: 6 April 2020. Accepted: 10 April 2020.

\begin{abstract}
The objective of this study was to analyze the psychometric properties of the Social Entrepreneurial Antecedents Scale (SEAS) with male and female university students in Mexico. There were 1,619 students from the University of Guadalajara and the Michoacan University of San Nicolas de Hidalgo who participated in the study. The reliability of SEAS was analyzed with Cronbach's alpha and the validity with confirmatory factor analysis using the maximum likelihood estimation method. Three factorial models of the scale were compared and items were added for its adaptation. The values produced by the factorial analysis show that the adapted Social Entrepreneurial Antecedents Scale presents adequate evidence of validity and reliability for university students in the central-western area of Mexico. It is shown that experience with Social Problems, Empathy, Moral Obligation, Self-Efficacy and Social Support favor the Intention of Social Entrepreneurship. This research provides elements for the identification of profiles of potential social entrepreneurs who can influence the development of populations with emerging economies, involving higher education institutions, government, business and society.
\end{abstract}

KEYWORDS: Factorial analysis, university, student, social entrepreneurship.

JEL CLASSIFICATION: L31, L26, D91.

Reference: Quiñonez Tapia, F., González-Betanzos, F., Vargas-Garduño, M. L. \& Aguirre Lozano, Z. E. (2020). Validation of the Social Entrepreneurial Antecedents Scale in University Students in Mexico. International Journal of Entrepreneurial Knowledge, 8(1), 1-18. doi: 10.37335/ijek.v8i2.97

\section{INTRODUCTION}

The Social Entrepreneurial Intentions is the willingness of a subject to carry out behaviors aimed at generating or maintaining social benefits, and is characterized by the development of a plan and the innovative use of resources to put into work any practice until an organization with a social mission is created (Mair \& Martí, 2006; Mair \& Noboa 2005, 2006). In addition, social entrepreneurship coexists with commercial entrepreneurship: Commercial activities allow the social entrepreneur the scaling and financial sustainability of their practices to achieve the social mission (Seelos \& Mair, 2007; Seelos, Mair, Battilana \& Tina Dacin, 2011).

The Organization for Economic Cooperation and Development (OECD, 2014), the World Bank (WB, 2017), the United Nations Organization for Education, Science and Culture (UNESCO, 2014) and the 


\section{INTERNATIONAL JOURNAL OF ENTREPRENEURIAL KNOWLEDGE}

Issue 1, volume 8, ISSN 2336-2960 (Online)

www.ijek.org

World Health Organization (WHO, 2017) have recognized social entrepreneurship as fundamental for the sustainable development of populations, since it not only generates jobs, but also addresses challenges in an innovative way and encourages the construction of fair, inclusive and democratic societies with privilege to the care of the environmental. In addition, social entrepreneurship has a relationship with social structure (Seelos et al., 2011), innovation (Mulloth, Kickul \& Gundry, 2016), identity capital (Lewis, 2016), creativity (Chell, Nicolopoulou \& Karatas-Özkan, 2010), social capital (Mair \& Martí, 2006; Westlund \& Gawell, 2012), social integration (Friedman \& Desivilya, 2010), geography (Smith \& Stevens, 2010), sustainable development (Seelos, Ganly \& Mair, 2006), politics and values (Cho, 2006; GarrigósSimón, González-Cruz \& Contreras-Pacheco, 2016), social innovation (Sabato, Vanhercke \& Verschraegen, 2017), marginalization, inequality and poverty (Mongelli \& Rullani, 2017), ethics (Dey \& Steyaert, 2014) and culture (Ferri, Noguera \& Urbano, 2015).

Likewise, Higher Education Institutions (HEI) have a determining role in generating and promoting entrepreneurship in societies, as long as they take into account the elements of entrepreneurship within the training of their students (Bartoš, Rahman, Horák, \& Jáčová, 2015; Bazan et al., 2019; Çera, Cepel, Zakutna, \& Rozsa, 2018; Cera, Mlouk, Cera, \& Shumeli, 2020; Dvorský, Petráková, Zapletalíková \& Rózsa, 2019; 2018; Sołtysiak, 2014). In this sense, social entrepreneurship, promoted from the university level, can influence a new development model for societies, without focusing only on the economic benefit of professionals or institutions (British Council, 2016, Escámez, Peris \& Escámez, 2017). In this way, various HEIs have developed programs for the training of social entrepreneurs: i.e. University of Salamanca, Spain; Centurion University of Technology and Management, India; University of Ljubljana, Slovenia; North-West University, South Africa; Maejo University, Thailand; Riara University, Kenya. Therefore, social entrepreneurship can be a professional outlet for graduates of HEIs.

Moreover, Mair and Noboa $(2005,2006)$ proposed the first Model of Social Entrepreneurial Intentions Formation and based it on the theory of planned behavior (Ajzen, 1991) and on the business behavior model (Shapero \& Sokol, 1982). According to Mair and Noboa, the Social Entrepreneurial Intention arises from Desirability and Feasibility: Desirability is the desire perceived by the subject to manifest a behavior aimed at generating social value and the Feasibility is the recognition of the possibility of carrying out such desire. In this way, Desirability is produced by the subject's ability to experience the situations and emotions of others (Empathy), in combination with the degree of responsibility assumed before such situation is experienced by others (Moral Judgment). Feasibility is constituted with the recognition of the ability to achieve change in certain situations (Self-efficacy) (Borzone, 2017), together with the ability to bring together more subjects that contribute to the implementation of actions promoting social change (Social Support) (Mair \& Noboa, 2005, 2006).

Subsequently, Hockerts (2015) built the Social Entrepreneurial Antecedents Scale (SEAS) based on the Mair and Noboa model $(2005,2006)$. The scale consists of 18 likert items made up of five points with four factors: Empathy, Moral Obligation, Self-efficacy and Social Support. Later, Hockerts (2017) added the Experience with Social Problems factor, defined as the practice of a subject with work in social organizations, as a predictor of the Social Entrepreneurial Intention. In this way, the Experience with Social Problems had a direct and indirect effect (mediated by Self-efficacy, Empathy, Social Support and Moral Obligation) on the Social Entrepreneurial Intention. As a result, Hockerts (2017) obtained an instrument of 19 response likert items made up of five points with six factors: Experience with Social Problems ( $\alpha=.78$ to .85$)$, Empathy ( $\alpha=.71$ to .76), Moral Obligation $(\alpha=.78$ to .90), Self-efficacy ( $\alpha=$ .69 to .77 ), Social Support ( $\alpha=.74$ to .86 ) and Social Entrepreneurial Intention ( $\alpha=.72$ to .83). Moreover, Ip, Wu, Liu and Liang (2017) evaluated the Hockerts (2017) model in university students in Hong Kong, and reported differences only in the Self-efficacy factor.

Mair and Noboa's (2005) theoretical model for promoting entrepreneurial intentionality for people and those proposed by Hockerts $(2015,2017)$ have not been tested in contexts of poverty. In this sense, and 


\section{INTERNATIONAL JOURNAL OF ENTREPRENEURIAL KNOWLEDGE}

Issue 1, volume 8, ISSN 2336-2960 (Online)

www.ijek.org

according to the National Council for the Evaluation of Social Development Policy (CONEVAL, 2016), $43.6 \%(53,418,200)$ of the population in Mexico lives in poverty because they have a monthly income of up to USD $\$ 187.27$, to satisfy the basic needs of food, education, health services, social security, quality and housing spaces. Based on the foregoing, the objective of the study was to evaluate the psychometric properties of the Social Entrepreneurial Antecedents Scale in university students in Mexico, so that its application can identify students interested in generating projects aimed at social benefits and intervene in an innovative way in the problems experienced by the populations of Mexico, to implement strategies that allow the development and strengthening of social projects in a collaborative way with civil society, business, government and academia.

\section{METHOD}

\subsection{Design}

This study was based on a quantitative design, not experimental and transversal to value the psychometric properties of the Social Entrepreneurial Antecedents Scale in university students in Mexico.

\subsection{Participants}

The total research sample was 1,619 university students between the ages of 18 to $28(\mathrm{M}=21.13, \mathrm{SD}=$ 2.73) from the University of Guadalajara (Northern University Center) and the Michoacan University of San Nicolas de Hidalgo. Both institutions were chosen because they are located in representative contexts of the dynamics of poverty in Mexico. 52.5\% $(47,495)$ of the population of the northern state of Jalisco (CONEVAL, 2015) and 55.3\% (2,708,600) of the population of the state of Michoacan (CONEVAL, 2016), experience poverty. The sample size complies with the recommendation of having ten participants for each item for psychometric evaluation procedures (Lloret-Segura, Ferreres-Traver, Hernández-Baeza \& Tomás-Marco, 2014; Velicer \& Fava, 1998).

\subsection{Instruments}

The Social Entrepreneurial Antecedents Scale was used (Hockerts, 2017) (see appendix). The original scale has 19 likert response items made up of five points, ranging from 1 (strongly disagree) to 5 (strongly agree), grouped into six factors: Experience with Social Problems (Items 1, 2, 3), Empathy (Items 6, 7, 8), Moral Obligation (Items 9, 10, 11, 12), Self-efficacy (Items 13, 14, 15), Social Support (Items 16, 17, 18) and Social Entrepreneurial Intention (Items 19, 20 ,21). Hockerts (2017) reported a Cronbach's alpha of the SEAS of .81.

To contextualize the scale to the situations of social entrepreneurship in Mexico, we added to SEAS four items in the factors of Experience with Social Problems (Items 4 and 5) and Intent of Social Entrepreneurship (Items 22 and 23), because the original scale limits the Experience with Social Problems and Intent of Social Entrepreneurship only to the dimension of employment participation of the subjects in legally constituted organizations. In addition, the items on the original scale were built with nascent social entrepreneurs studying for a master's degree at the business school in Denmark - a country with an advanced economy in the world (OECD, 2019) - and the scale was validated with undergraduate and master students from the same institution. Therefore, for the Mexican context, we consider that the Experience and Intention with Social Entrepreneurship includes other levels of participation of the subjects that range from the practices with some social group, activity or project destined to generate social value, all the way to the participation and constitution of a legal social company. Likewise, the four items that were included in the original scale were proposed based on the fact that, regardless of the area of university education, Mexican students who grow up in contexts of poverty, have daily experiences 


\section{INTERNATIONAL JOURNAL OF ENTREPRENEURIAL KNOWLEDGE}

Issue 1, volume 8, ISSN 2336-2960 (Online)

www.ijek.org

with social challenges. Furthermore, we consider that such daily experiences enable Mexican students to have the intention of participating in some activity, group or project aimed at solving the problems they observe and experience in their development context.

\subsection{Procedure}

The researchers adapted the SEAS into Spanish with standards and guidelines of reverse translation (Eremenco, Cella \& Arnold, 2005; Van de Vijver \& Tanzer, 1997). We compared the original version and the translated version until we found no relevant differences. Subsequently, we requested eight male students and seven female students to review the items and any questions in understanding were written down and discussed again with the whole group until we obtained the final version of the Social Entrepreneurial Antecedents Scale.

We contacted the directors of both participating universities to obtain the permission to apply the instrument in their respective institution. We located the sample in their class schedules, and with the consent of the teaching staff, we invited the students to participate. Those who accepted gave informed consent. The application was self-administered in a group setting and we only clarified questions regarding the instructions.

\subsection{Statistical Analysis}

We performed the internal reliability analysis of the SEAS with Cronbach's alpha. We evaluated the validity of the Social Entrepreneurial Antecedents Scale of the model proposed by Hockerts (2015) with the Confirmatory Factorial Analysis (CFA). We used the Maximum Likelihood (ML) method because the data presented multivariate normality: We established a value less than two for kurtosis and skewness as an indicator of normality (see Table 1). Subsequently, we looked for evidence of validity in relation to the scale to test the theoretical model proposed by Hockerts (2017).

The researchers involved calculated the following parameters to assess the fit of the data to the models under analysis: chi-square $(\chi 2)$, chi-square ratio over degrees of freedom $\left(\chi^{2} /\right.$ gl), goodness of fit index (GFI), root mean square error of approximation (RMSEA), normed fit index (NFI), Turker-Lewis index (TLI), incremental index of fit (IFI), adjusted goodness-of-fit index (AGFI), comparative fit index (CFI) and Akaike information criterion (AIC). In addition, we established the chi-square value over degrees of freedom under two; GFI, NFI, TLI, CFI, IFI and AGF equal to or greater than .90; and RMSEA equal to or less than .05 to determine acceptable fit of the data to the models, and we established the criteria of choosing the model with the lowest AIC value as the best (Byrne, 2016; Hair, Anderson, Tatham \& Black, 1999; Lomax \& Schumacker, 2004). Moreover, the analysis of the missing data was based on the assumption of the absence of random data, and they were treated with the method of imputation of linear interpolation. Finally, we used the SPSS-IBM 21 and SPSS Amos-IBM 21 software to perform the statistical analyses.

\subsection{Ethical Aspects}

The study had the ethical rigor established in the code of ethics of the psychologist (Mexican Society of Psychology [MSP], 2010) and in the Regulation of the General Law of Health in matters of health research in Mexico (1987). Therefore, we considered our study without risk to the health of the participants. Likewise, we guaranteed the confidentiality and voluntary participation (expressed with the written consent) of the subjects. Finally, the research was approved by ethics committees of the University of Guadalajara and the Michoacan University of San Nicolas de Hidalgo. 
INTERNATIONAL JOURNAL OF ENTREPRENEURIAL KNOWLEDGE

Issue 1, volume 8, ISSN 2336-2960 (Online)

www.ijek.org

\section{RESULTS}

The participants obtained an average of $48.37(\mathrm{SD}=8.68)$ in the total SEAS score. The data presented multivariate normality: The analysis of the items yielded values of skewness in a range of -1.03 to 0.68 , and values of kurtosis in a range of -1.01 to 1.93. Also, Table 1 shows the sample size $-\mathrm{n}$, percentage - $\%$, average scores -median, and standard deviations -SD.

\section{Table 1 Average scores in the Social Entrepreneurial Antecedents Scale}

\begin{tabular}{|c|c|c|c|c|}
\hline Variable & $\mathrm{n}$ & $\%$ & Median & $\mathrm{SD}$ \\
\hline \multicolumn{5}{|l|}{ Sex } \\
\hline Women & 862 & 53.2 & 49.52 & 8.33 \\
\hline Men & 757 & 46.8 & 47.06 & 8.89 \\
\hline \multicolumn{5}{|l|}{ Age (years) } \\
\hline 25 to 29 & 189 & 11.7 & 50.13 & 9.81 \\
\hline 20 to 24 & 825 & 51 & 48.04 & 8.51 \\
\hline 18 to 19 & 605 & 37.4 & 47.47 & 8.45 \\
\hline \multicolumn{5}{|l|}{ University } \\
\hline Michoacana University of San Nicolas de Hidalgo & 1,365 & 84.3 & 48.50 & 8.86 \\
\hline $\begin{array}{l}\text { University of Guadalajara/Northern University } \\
\text { Center }\end{array}$ & 254 & 15.7 & 47.65 & 7.65 \\
\hline \multicolumn{5}{|l|}{ Semesters } \\
\hline 4 to 9 & 751 & 46.4 & 48.60 & 8.9 \\
\hline 1 to 4 & 868 & 53.6 & 48.17 & 8.49 \\
\hline \multicolumn{5}{|l|}{ Areas of Knowledge $\mathrm{a}^{\mathrm{a}}$} \\
\hline Social Science, Commercial Education and Law & 768 & 47.4 & 49.81 & 8.86 \\
\hline Arts and Humanities & 25 & 1.5 & 49.60 & 7.17 \\
\hline Science & 120 & 7.4 & 47.93 & 9.14 \\
\hline Health and Social Services & 465 & 28.7 & 47.44 & 8.05 \\
\hline Engineering, Industry and Construction & 241 & 14.9 & 45.65 & 8.35 \\
\hline \multicolumn{5}{|l|}{ Areas of Knowledge/Degrees } \\
\hline \multicolumn{5}{|l|}{ Science } \\
\hline Biology & 120 & 7.4 & 47.93 & 9.14 \\
\hline \multicolumn{5}{|l|}{ Social Science, Commercial Education and Law } \\
\hline Economics & 50 & 3.1 & 61.80 & 3.51 \\
\hline Anthropology & 4 & 0.2 & 51.25 & 4.57 \\
\hline Psychology & 321 & 19.8 & 50.55 & 8.7 \\
\hline Administration & 86 & 5.3 & 48.93 & 8.56 \\
\hline Public Accountant & 153 & 9.5 & 47.50 & 8.12 \\
\hline Attorney & 128 & 7.9 & 47.39 & 8.12 \\
\hline Agrobusiness & 30 & 1.9 & 46.82 & 7.49 \\
\hline \multicolumn{5}{|l|}{ Arts and Humanities } \\
\hline Fine Arts & 25 & 1.5 & 49.60 & 7.17 \\
\hline \multicolumn{5}{|l|}{ Engineering, Industry and Construction } \\
\hline Civil Engineering & 75 & 4.6 & 47.21 & 6.09 \\
\hline Electrical Mechanics & 23 & 1.4 & 46.37 & 4.69 \\
\hline Chemical Engineering & 90 & 5.6 & 45.47 & 10.19 \\
\hline
\end{tabular}


INTERNATIONAL JOURNAL OF ENTREPRENEURIAL KNOWLEDGE Issue 1, volume 8, ISSN 2336-2960 (Online)

www.ijek.org

\begin{tabular}{|l|l|c|c|c|c||}
\hline \hline & Architecture & 25 & 1.5 & 43.72 & 6.12 \\
\hline & Electronics and Computer Systems & 24 & 1.5 & 41.87 & 10.53 \\
\hline \multicolumn{4}{||l|}{ Health and Social Services } & \multicolumn{4}{|l|}{} \\
\hline & Nursing & 197 & 12.2 & 48.27 & 8.25 \\
\hline & Dental Surgeon & 197 & 12.2 & 47.26 & 8.44 \\
\hline & Nutrition & 21 & 1.3 & 45.62 & 8.99 \\
\hline & Medicine & 50 & 3.1 & 45.60 & 4.02 \\
\hline
\end{tabular}

(Source: own research data)

Note. $N=254$; SD = Standard Deviation (Source: Research Data 2019)

${ }^{a}$ International Normalized Classification of Education CINE 2001 (UNESCO, 2011)

\subsection{Confirmatory Factorial Analysis (CFA)}

Figure 1 Confirmatory Factorial Analysis of the Social Entrepreneurial Antecedents Scale applied in Mexico

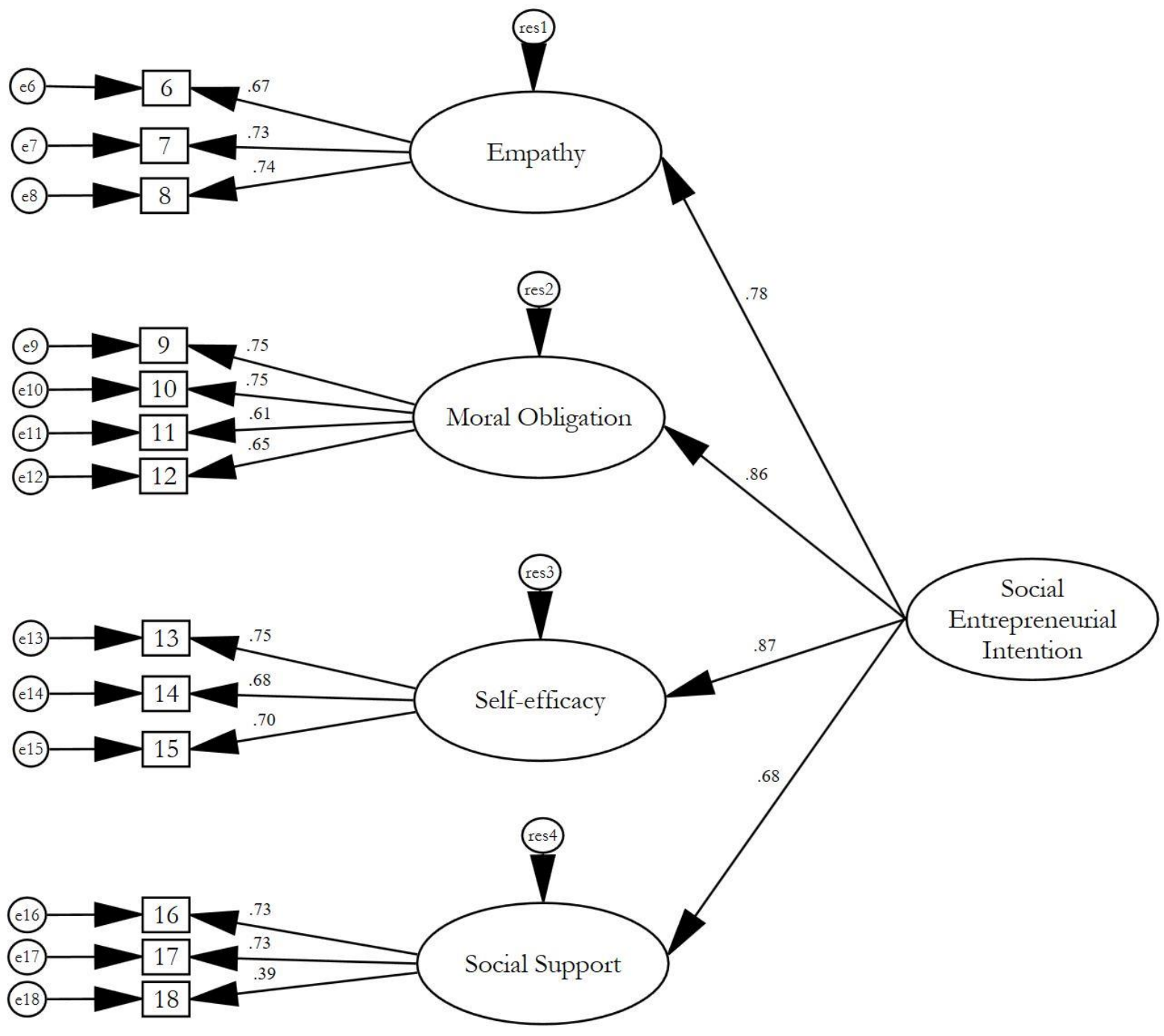

(Source: Research Data 2019) 


\section{INTERNATIONAL JOURNAL OF ENTREPRENEURIAL KNOWLEDGE}

Issue 1, volume 8, ISSN 2336-2960 (Online)

www.ijek.org

The CFA of the Hockerts (2015) model yielded the following global adjustment measures: $\chi^{2}=412$, gl $=61, \mathrm{p}<.001$. The global adjustment values indicate the rejection of the null hypothesis, because of the differences between the theoretical and empirical matrix, which is very common for samples greater than 200 cases; therefore, Hair et al. (1999) has suggested using the chi-square ratio on degrees of freedom $\left(\chi^{2}\right.$ $/ \mathrm{gl})$ and other indexes. Thus, the analysis of the data to the Hockerts (2015 a) model showed a very good fit: $\chi^{2} / \mathrm{gl}=6.75$, GFI $=.96$ and RMSEA $=.06$, NFI $=.94$, TLI $=.94$, IFI $=.95$, CFI $=.95$, AGFI $=$ .94. As a result, the Social Entrepreneurial Intention in university students in Mexico is explained by Empathy, Moral Obligation, Self-efficacy and Social Support. However, the factors of Self-efficacy and Moral Obligation have greater explanatory effect, unlike Social Support, as shown in Figure 1.

\subsection{Reliability}

The internal reliability analysis of the SEAS (Hockerts, 2015) yielded a value of Cronbach's alfa of .85: Empathy $(\alpha=.76)$, Moral Obligation $(\alpha=.78)$, Self-efficacy $(\alpha=.75)$ and Social Support $(\alpha=.60)$.

\subsection{Determinants of the Social Entrepreneurial Intention}

The modified model of Hockerts (2017) and its derivatives, and that of a second order factor, were analyzed for the search for evidence of validity of the SEAS. Table 3 shows the adjustment rates for the models analyzed. It is observed that the second order Hockerts (2017) model, showed values that indicate an adequate fit of the data.

\section{Table 2 SEAS goodness of fit indexes in Mexico}

\begin{tabular}{|c|c|c|c|c|c|c|c|c|c|c|c|c|}
\hline Models & $N$ & $\chi^{2}$ & $g l$ & $\chi^{2} / g l$ & RMSEA & GFI & AGFI & CFI & IFI & NFI & TLI & AIC \\
\hline $\begin{array}{l}(1) \begin{array}{l}\text { Hockerts, } \\
2017 \text { original }^{\text {a }}\end{array} \\
\end{array}$ & 1619 & $1583^{*}$ & 143 & 11.07 & .08 & .89 & .86 & .85 & .85 & .84 & .82 & 1677 \\
\hline 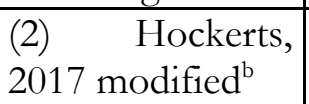 & 1619 & $2229^{*}$ & 221 & 10.08 & .07 & .88 & .85 & .85 & .85 & .84 & .83 & 2339 \\
\hline $\begin{array}{lr}(3) & \text { Hockerts, } \\
2017 & \text { second } \\
\text { order } & \\
\end{array}$ & 1619 & $770^{*}$ & 127 & 6.06 & .05 & .95 & .93 & .94 & .94 & .93 & .93 & 858 \\
\hline
\end{tabular}

(Source: own research data)

Note: The indicators with better fit appear in bold. (Source: Research Data 2019)

a Observable variables: Empathy, Moral Obligation, Self-efficacy, Social Support, Experience and Social Entrepreneurial Intention.

b There are four items added to the Hockerts (2017) model: two of them to the factor of Experience with Social Problems (4 y 5) and two of them to the factor of Social Entrepreneurial Intention (22 y 23).

c Observable variables: Empathy, Moral Obligation, Self-efficacy, Social Support and Previous experience with Social Problems; Latent Variable: Social Entrepreneurial Intention.

$*_{\mathrm{p}}<.05$

Moreover, Figure 2 shows the original Hockerts (2017) model and estimated parameters. Strong effects can be observed of the Experience with Social Problems on Empathy, Moral Obligation, Self-efficacy and Social Support. The effects of the Experience with Social Problems, Self-efficacy and Social Support on the Intention were moderate, unlike Empathy and Moral Obligation where the effect was not significant ( $p>0.05)$. It also shows moderate effects of the items on the Experience with Social Problems. 
INTERNATIONAL JOURNAL OF ENTREPRENEURIAL KNOWLEDGE

Issue 1, volume 8, ISSN 2336-2960 (Online)

www.ijek.org

Figure 2 Model: Hockerts, 2017 original

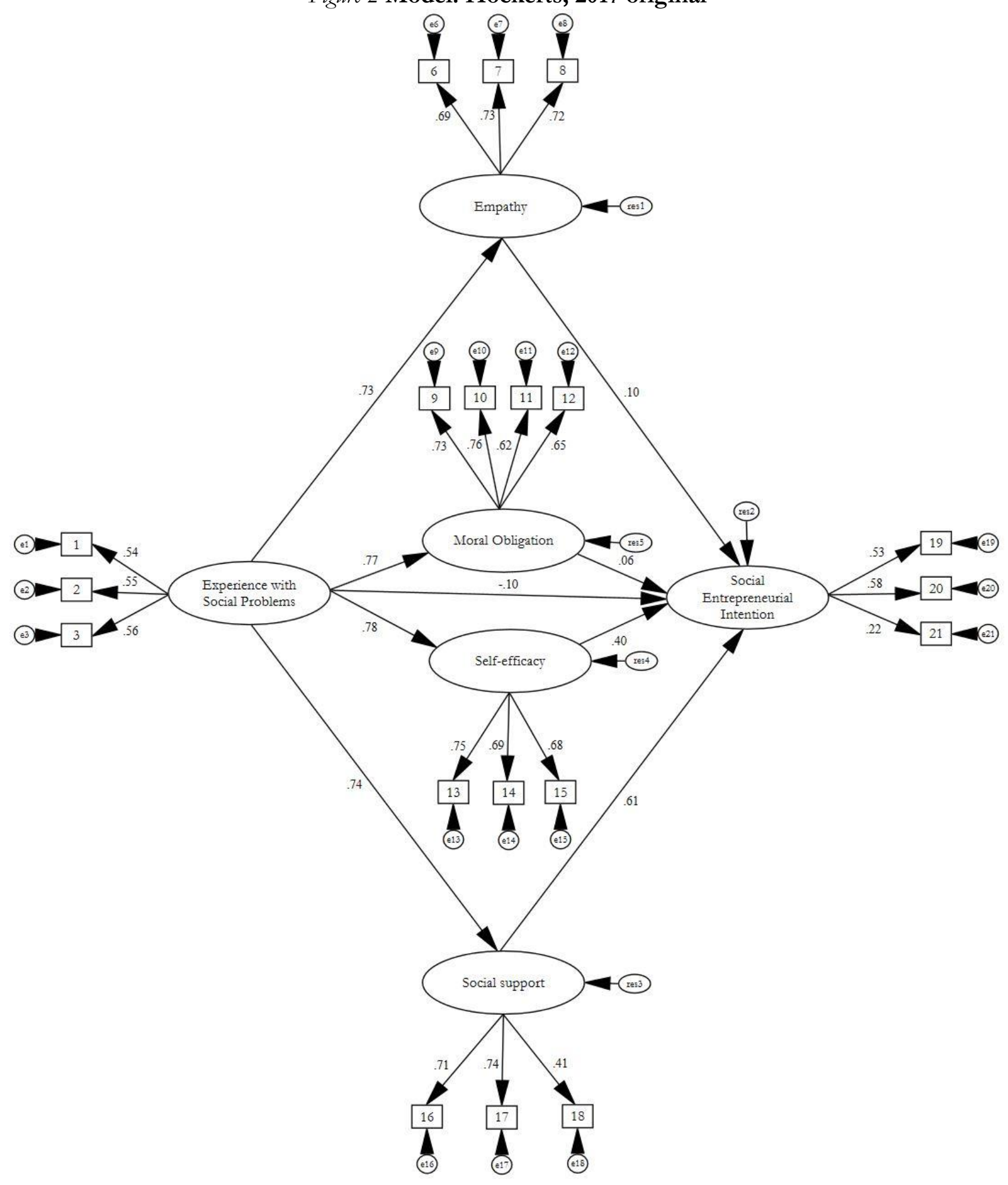

(Source: Research Data 2019) 
INTERNATIONAL JOURNAL OF ENTREPRENEURIAL KNOWLEDGE

Issue 1, volume 8, ISSN 2336-2960 (Online)

www.ijek.org

The adjustments done to the Hockerts model, 2017 modified, implied that the inclusion of the items 4 $(\lambda=.80)$ and $5(\lambda=.75)$ in the factor of Experiences with Social Problems and the items $22(\lambda=.68)$ and $23(\lambda=.63)$ in the factor of Intention of Social Entrepreneurship, would generate the following changes. The Experiences with Social Problems diminished its effect over Empathy $(\lambda=.54)$, Moral Obligation $(\lambda=.52)$, Self-efficacy $(\lambda=.50)$, and Social Support $(\lambda=.61)$. On the other hand, Empathy $(\lambda=.12)$ and Moral Obligation $(\lambda=.19)$ increased their effect over the Intention of Social Entrepreneurship; while Self-efficacy $(\lambda=.30)$ and Social Support $(\lambda=.46)$ diminished their effect over the variable of the Intention of Social Entrepreneurship. Finally, the Experience with Social Problems does not explain the Intention of Social Entrepreneurship $(\lambda=.06)$.

Finally, the model of the final solution, beginning with Hockerts (2017) modified, indicated an adequate fit to the data of the study $\left(\mathrm{N}=1619, \chi^{2}=770, \mathrm{gl}=127, \chi^{2} / \mathrm{gl}=6.06\right.$, RMSEA $=.05$, CFI $=.94$, GFI $=.95)$. In this way, the Experience with Social Problems predicted the Social Entrepreneurial Intention mediated by Empathy, Moral Obligation, Self-efficacy and Social Support. Besides, the Social Entrepreneurial Intention showed up as a second order variable, as shown on Figure 3. 
INTERNATIONAL JOURNAL OF ENTREPRENEURIAL KNOWLEDGE

Issue 1, volume 8, ISSN 2336-2960 (Online)

www.ijek.org

Figure 3 Model: Hockerts, 2017 second order

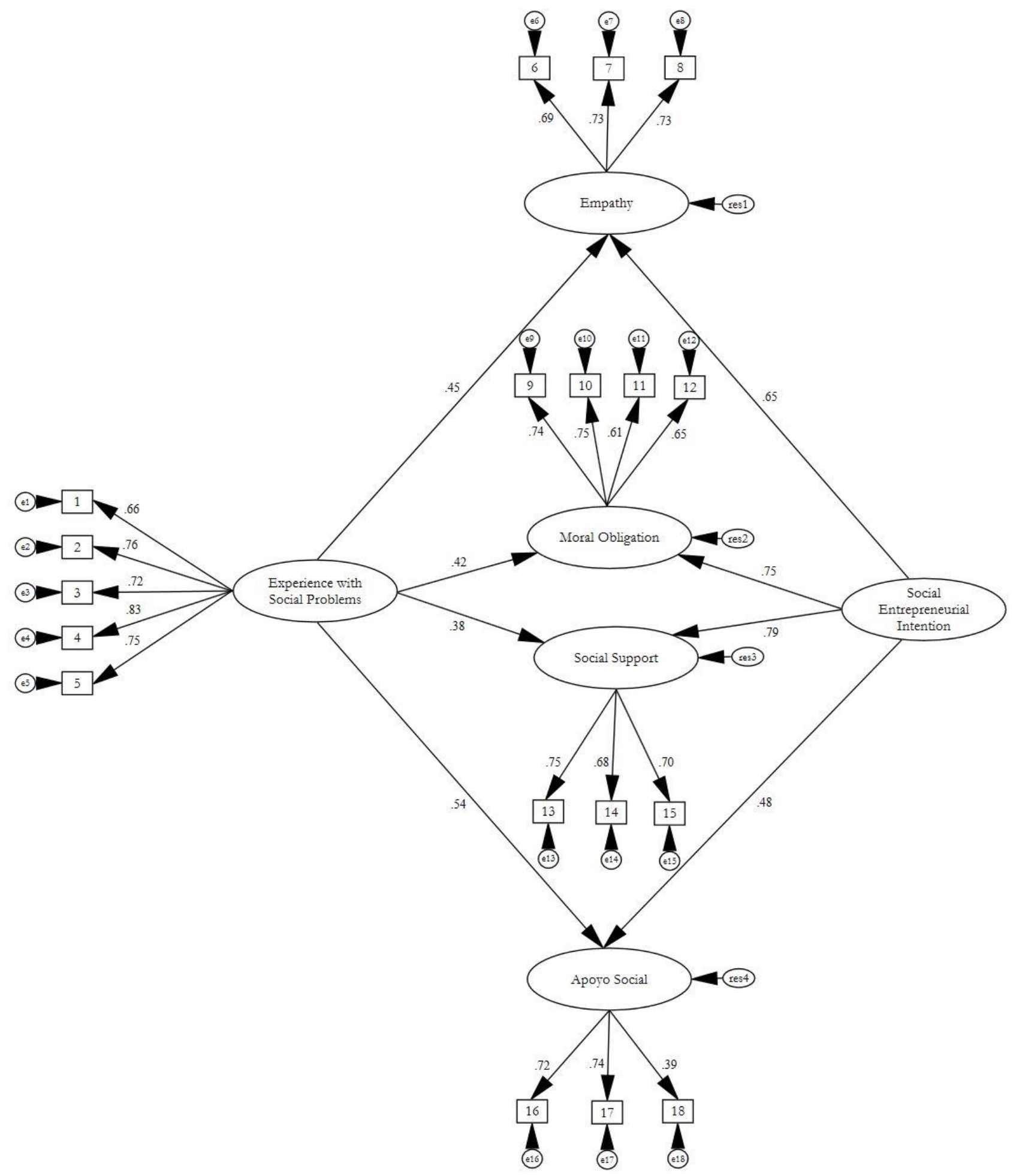

(Source: Research Data 2019) 


\section{INTERNATIONAL JOURNAL OF ENTREPRENEURIAL KNOWLEDGE}

Issue 1, volume 8, ISSN 2336-2960 (Online)

www.ijek.org

\section{DISCUSSION}

The objective of this study was to analyze the psychometric properties of the Social Entrepreneurial Antecedents Scale in university students in Mexico. We analyzed the reliability and validity of SEAS. We demonstrated that the Social Entrepreneurial Antecedents Scale proposed by Hockerts (2015) is valid and reliable for the population of our research. This is the first study in the world that empirically analyzes, in a context of poverty, the approaches to the formation of social entrepreneurial intentions proposed by Mair and Noboa (2005) and those developed by Hockerts (2015, 2017).

We reported as reliable $(\alpha=.88)$ the Social Entrepreneurial Antecedents Scale for university students in Mexico. Likewise, we demonstrated the validity of SEAS with four factors: Empathy, Moral Obligation, Self-efficacy and Social Support that predict the Social Entrepreneurial Intention. In this way, we agreed with the results reported by Hockerts (2015) in business students of the University of Copenhagen in Denmark. In addition, we reported that Self-efficacy, Empathy and Obligation were factors with greater influence to explain the Social Entrepreneurial Intention in university students in Mexico living in poverty, and the above coincided with what was reported by Hockerts (2015) and with only the Empathy factor that reported Ip et al. (2017). In contrast, the results of Ip et al. (2017) were different from those obtained in our study and those of Hockerts $(2015,2017)$ in the Self-efficacy factor: Ip et al. reported Self-efficacy without association with the Social Entrepreneurial Intention.

In addition, our results and those of Hockerts $(2015,2017)$ showed that Social Support was a factor that explained the Social Entrepreneurial Intention and was considered as an element of feasibility as established by Mair and Noboa (2006). However, in our study, Social Support obtained a lower weight unlike the other factors, which contrasted with the results of Hockerts (2015) and Ip et al. (2017), who reported a strong weight for the Social Support factor, for the explanation of the Social Entrepreneurial Intention.

Likewise, the Moral Obligation factor reported by Ip et al. (2017) in Hong Kong was different than our results and those of Hockerts (2015) in Denmark, because the researchers of Ip et al. found the factor with a negative effect on the Social Entrepreneurial Intention. Therefore, it is suggested to design and implement interventions and programs that develop and/or strengthen the personality trait of Empathy and Self-efficacy in populations of poverty, to educate residents with a strong social commitment to perform actions for the benefit of the population.

Experience with Social Problems is a predictor of the Social Entrepreneurial Intention and this causal relationship is mediated by Empathy, Moral Obligation, Self-efficacy and Social Support (Hockerts, 2017). We demonstrated that the Experience with Social Problems was a predictor of the Social Entrepreneurial Intention, with strong effects on mediating factors, besides the model yielding an adequate fit. The foregoing coincided with that reported by Hockerts (2017) in the students of Denmark and with Ip et al. (2017) with the students in Hong Kong, who reported a strong effect of the Experience with Social Problems on the Social Entrepreneurial Intention mediated by Self-efficiency and Empathy; a moderate effect mediated by the Moral Obligation and an acceptable fit of the model, as well as a strong effect on the Social Entrepreneurial Intention variable. Likewise, we agreed with Hockerts $(2015,2017)$ with acceptable reliability coefficients in each factor.

In contrast, we differed with Hockerts (2017) and Ip et al. (2017) with the Social Entrepreneurial Intention variable, because they presented this variable as observable and in the final solution of our study it emerged as a latent variable of the second order. Therefore, it is important to improve the sensitivity in the items that are direct indicators of the Social Entrepreneurial Intention. This difference can occur because the items that are proposed in the original scale only contemplate the participation of the subjects in social organizations or in the constitution of the social enterprise, and for the population 


\section{INTERNATIONAL JOURNAL OF ENTREPRENEURIAL KNOWLEDGE}

Issue 1, volume 8, ISSN 2336-2960 (Online)

www.ijek.org

of this study it is possibly not visualized in this way, but as participation in projects or groups to help others socially. As can be observed in the results, the original items that measure Social Entrepreneurial Intention presented a low reliability that improved by including items that are aimed at contemplating the participation of the subjects in groups, activities and projects that are dedicated to solving social problems. Therefore, it is important to explore from qualitative studies the conceptions that exist in Mexico about the Social Entrepreneurial Intention. In this way, there will be conditions to build a scale with greater sensitivity that allows for the measurement in an observable way of the Social Entrepreneurial Intention, and then allows us to integrate it to the model proposed by Hockerts (2017) in the observable search for the determining factors of the Social Entrepreneurial Intention. From the above, it is hypothesized that the model proposed by Hockerts (2017) will be adjusted in Mexican university students.

\section{CONCLUSIONS}

Our study has practical implications. It is the first study done in Mexico that presents an instrument with validity and reliability to identify the students of higher education with intentions towards social entrepreneurship, who may be interested in proposing and carrying out projects to solve problems related to education, food, health, social security, environment, quality of life, living spaces, among others, and in which the government and the market do not intervene. In addition, the detection of the Social Entrepreneurial Intention constitutes the first step to detonate practices, projects and organizations that promote social benefit over economic benefit (Hockerts, 2015; Mair \& Noboa, 2006), based on the training and advice of the possible entrepreneurs, and then start the implementation of these projects and practices and finally reach the constitution of the social enterprise (Mair \& Noboa, 2006).

Therefore, we recommend the use of this instrument to identify profiles with an interest in Social Entrepreneurship in higher level students, in order to support them to materialize the projects, programs and social enterprises required in societies with poverty, in Mexico and in other countries with emerging economies. If Higher Education Institutions emphasize training in factors such as empathy, moral obligation, self-efficacy and social support, as well as experiences with social problems, they will be promoting the generation of the intention of social entrepreneurship. By promoting the transition from intention to the implementation of social entrepreneurship until the constitution of a social enterprise, the link between higher education, government, business and society will be affected; and with this, a greater commitment of the students to society will be promoted, not only as a means to obtain personal financial resources. Young people have the potential to become fundamental actors in the construction of the social fabric (Ayala, 2005), and social entrepreneurship can be a way to achieve it.

The study has its strength in the method, because it has a reliable and optimal sample for validation of instruments in accordance with the contemporary and classical theory of the tests, for its translation procedure and instrumentation in the field and its ethical management, as well as the application of structural equations for data analysis. In contrast, the study is limited to students of higher education; therefore, it is recommended in future research studies to include other population segments with potential for social entrepreneurship.

Other lines of research can be derived from this study, such as: the modification of curricular designs to promote the training of students in the dimensions involved in increasing the intention of social entrepreneurship; the generation of student experiences in addressing social problems, from co-curricular spaces, taking advantage of policies to support the practice of corporate social responsibility; the incorporation of prior training processes that strengthen the dimensions that have a positive impact on social entrepreneurship, before implementing the financed social projects offered by the government, to achieve greater cohesion within the work groups and, therefore, greater efficiency. 


\section{INTERNATIONAL JOURNAL OF ENTREPRENEURIAL KNOWLEDGE}

Issue 1, volume 8, ISSN 2336-2960 (Online)

www.ijek.org

\section{REFERENCES}

Ajzen, I. (1991). The theory of planned behavior. Organizational Behavior and Human Decision Processes, 50(2), 179-211. doi:10.1016/0749-5978(91)90020-t

Ayala, N. (2005, sept). Fortalecimiento del grupo de consejeros locales de juventud en la localidad de Ciudad Bolívar desde los procesos de participación política y comunitaria. [Strengthening of the group of local youth advisers in the town of Ciudad Bolívar from the processes of political and community participation] Acta Colombiana de Psicología, 14, 33-52. Retrieved from https://editorial.ucatolica.edu.co/ojsucatolica/revistas_ucatolica/index.php/acta-colombianapsicologia/article/view/423/423

Bartoš, P., Rahman, A., Horák, J., \& Jáčová, H. (2015). Education and Entrepreneurship in the SME Segment in Economic Transformation. Economics \& Sociology, 8(2), 227-239. doi:10.14254/2071789x.2015/8-2/16

Bazan, C., Datta, A., Gaultois, H., Shaikh, A., Gillespie, K. \& Jones, J. (2019). Effect of the University in the Entrepreneurial Intention of Female Students. International Journal of Entrepreneurial Knowledge, 7(2), 73-97. doi:10.12345-0012

Borzone, M.A. (2017). Autoeficacia y vivencias académicas en estudiantes universitarios. [Self-efficacy and academic experiences in university students]. Acta Colombiana de Psicología, 20(1), 266-274. doi.org/10.14718/ACP.2017.20.1.13

British Council. (2016). Social enterprise in a global context. The role of higher educations institutions. London: Author.

Byrne, B. M. (2016). Structural equation modeling with AMOS: basic concepts, applications, and programming (2. ed.). USA: Routledge.

Çera, G., Cepel, M., Zakutna, S., \& Rozsa, Z. (2018). Gender differences in perception of the university education quality as applied to entrepreneurial intention. Journal of International Studies, 11(3), 147160. doi:10.14254/2071-8330.2018/11-3/13

Cera, G., Mlouk, A., Cera, E., \& Shumeli, A. (2020). The Impact of Entrepreneurship Education on Entrepreneurial Intention. A Quasi-Experimental Research Design. Journal of Competitiveness, 12(1), 39- 56. https://doi.org/10.7441/joc.2020.01.03

Chell, E., Nicolopoulou, K., \& Karatas-Özkan, M. (2010). Social entrepreneurship and enterprise: International and innovation perspectives. Entrepreneurship \& Regional Development, 22(6), 485-493. doi:10.1080/08985626.2010.488396

Cho, A. H. (2006). Politics, values and social entrepreneurship: A critical appraisal. In J. Mair, J. Robinson, \& K. Hockerts (Eds.), Social Entrepreneurship (pp. 34-56). United States, United Kingdom: Palgrave Macmillan UK.

Consejo Nacional de Evaluación de Política de Desarrollo Social (CONEVAL) (2015). Medición de la pobreza municipal, Estados Unidos Mexicanos, 2010-2015 (Base de Datos). [Municipal poverty measurement, United Mexican States, 2010-2015 (Database)]. Retrieved from https://www.coneval.org.mx/Medicion/Paginas/AE_pobreza_municipal.aspx.

Consejo Nacional de Evaluación de Política de Desarrollo Social (CONEVAL) (2016). Medición de la pobreza, Estados Unidos Mexicanos, 2010-2015 (Base de Datos). [Poverty measurement, United Mexican States, 2008-2016 (Database)]. Retrieved from https://www.coneval.org.mx/Medicion/MP/Paginas/AE_pobreza_2018.aspx

Dey, P., \& Steyaert, C. (2014). Rethinking the space of ethics in social entrepreneurship: Power, subjectivity, and practices of freedom. Journal of Business Ethics, 133(4), 627-641. doi:10.1007/s10551-014-2450-y

Dvorský, J., Petráková, Z., Zapletalíková, E., \& Rózsa, Z. (2019). Entrepreneurial propensity index of university students. The case study from the Czech Republic, Slovakia and Poland. Oeconomia Copernicana, 10(1), 173-192. doi.org/10.24136/oc.2019.009 


\section{INTERNATIONAL JOURNAL OF ENTREPRENEURIAL KNOWLEDGE}

Issue 1, volume 8, ISSN 2336-2960 (Online)

www.ijek.org

Eremenco, S. L., Cella, D., \& Arnold, B. J. (2005). A comprehensive method for the translation and cross-cultural validation of health status questionnaires. Evaluation \& the Health Professions, 28(2), 212-232. doi:10.1177/0163278705275342

Escámez, J., Peris,J. y Escámez, J.I. (abril/junio, 2017). Educación de los estudiantes universitarios y gestión de la sostenibilidad. [University student education and sustainability management] Perfiles Educativos, 39(156),174-190. Retrieved from http:/ / www.scielo.org.mx/scielo.php?script=sci_arttext\&pid=S018526982017000200174\&lng=es\&nrm=iso\&tlng=es

Ferri, E., Noguera, M., \& Urbano, D. (2015). The effect of cultural factors on social entrepreneurship: The impact of the economic downturn in Spain. En M. Peris-Ortiz \& J. M. Merigó-Lindahl (Eds.), Entrepreneurship, regional development and culture (pp. 75-87). USA: Springer International Publishing.

Friedman, V. J., \& Desivilya, H. (2010). Integrating social entrepreneurship and conflict engagement for regional development in divided societies. Entrepreneurship \& Regional Development, 22(6), 495-514. doi:10.1080/08985626.2010.488400

Garrigós Simón, F. J., González-Cruz, T., \& Contreras-Pacheco, O. (2016). Policies to enhance social development through the promotion of SME and social entrepreneurship: A study in the Colombian construction industry. Entrepreneurship \& Regional Development, 29(1-2), 51-70. doi:10.1080/08985626.2016.1255437

Hair, J. F., Anderson, R. E., Tatham, R. L., \& Black, W. C. (1999). Análisis multivariante. [Multivariate analysis] Madrid: Prentice Hall.

Hockerts, K. (2015). The Social Entrepreneurial Antecedents Scale (SEAS): A validation study. Social Enterprise Journal, 11(3), 260-280. doi:10.1108/sej-05-2014-0026

Hockerts, K. (2017). Determinants of social entrepreneurial intentions. Entrepreneurship Theory and Practice, 41(1), 105-130. doi:10.1111/etap.12171

Ip, C. Y., Wu, S.-C., Liu, H.-C., \& Liang, C. (2017). Revisiting the antecedents of social entrepreneurial intentions in Hong Kong. International Journal of Educational Psychology, 6(3), 301. doi:10.17583/ijep.2017.2835

Lewis, K. V. (2016). Identity capital: an exploration in the context of youth social entrepreneurship. Entrepreneurship \& Regional Development, 28(3-4), 191-205. doi:10.1080/08985626.2016.1155741

Lloret-Segura, S., Ferreres-Traver, A., Hernández-Baeza, A., \& Tomás-Marco, I. (2014). El análisis factorial exploratorio de los ítems: una guía práctica, revisada y actualizada. [The exploratory factor analysis of the items: a practical, revised and updated guide] Anales de Psicología, 30(3). 1151 1169. doi:10.6018/analesps.30.3.199361

Lomax, R. G., \& Schumacker, R. E. (2004). A beginner's guide to structural equation modeling. USA: Psychology Press.

Mair, J., \& Martí, I. (2006). Social entrepreneurship research: A source of explanation, prediction, and delight. Journal of World Business, 41(1), 36-44. doi:10.1016/j.jwb.2005.09.002

Mair, J., \& Noboa, E. (2006). Social entrepreneurship: How intentions to create a social venture are formed. In J. Mair, J. Robinson, and K. Hockerts (Ed.), Social entrepreneurship (pp. 121-135). United Kingdom: Springer.

Mair, J., \& Noboa, E. (junio, 2005). How intentions to create a social venture are formed: A case study. SSRN Electronic Journal. Retrieved from http://dx.doi.org/10.2139/ssrn.875589

Mongelli, L., \& Rullani, F. (2017). Inequality and marginalisation: social innovation, social entrepreneurship and business model innovation. Industry and Innovation, 24(5), 446-467. doi:10.1080/13662716.2017.1295365

Mulloth, B., Kickul, J. R., \& Gundry, L. K. (2016). Driving technology innovation through social entrepreneurship at Prezi. Journal of Small Business and Enterprise Development, 23(3), 753-767. doi:10.1108/jsbed-08-2015-0111

Organization for Economic Co-operation and Develpment (OECD) (2014). Job creation in the social economy and social entrepreneurship. In Organization for Economic Co-operation and Develpment (Ed), Job Creation and Local Economic Development (pp. 141-158). Paris: Autor. 


\section{INTERNATIONAL JOURNAL OF ENTREPRENEURIAL KNOWLEDGE}

Issue 1, volume 8, ISSN 2336-2960 (Online)

www.ijek.org

Organization for Economic Co-operation and Develpment (OECD) (2019), Economic Policy Reforms 2019: Going for Growth, OECD Publishing, Autor, https://doi.org/10.1787/aec5b059-en.

Reglamento de la ley general de salud en materia de investigación para la salud, 6 de enero de 1987. Camara de Diputados México (1987) (Legislado). Retrieved from http://www.ordenjuridico.gob.mx/Documentos/Federal/html/wo88535.html

Sabato, S., Vanhercke, B., \& Verschraegen, G. (2017). Connecting entrepreneurship with policy experimentation? The EU framework for social innovation. Innovation: The European Journal of Social Science Research, 30(2), 147-167. doi:10.1080/13511610.2017.1282308

Seelos, C., \& Mair, J. (2007). How social entrepreneurs enable human, social, and economic development. En J. A. Q. . Kashturi Rangan, Gustavo Herrero, Brooke Barton (Ed.), Business solutions for the global poor: Creating social and economic value (pp. 271-294). USA: Jossey-Bass.

Seelos, C., Ganly, K., \& Mair, J. (2006). Social entrepreneurs directly contribute to global development goals. En J. Mair, J. Robinson, \& K. Hockert (Eds.), Social entrepreneurship (pp. 235-275). United States, United Kingdom: Palgrave Macmillan UK.

Seelos, C., Mair, J., Battilana, J., \& Tina Dacin, M. (2011). The embeddedness of social entrepreneurship: Understanding variation across local communities. En C. Marquis, M. Lounsbury \& R.Greenwood (Eds.), Communities and Organizations (pp. 333-363): Emerald Group Publishing Limited.

Shapero, A., \& Sokol, L. (1982). The social dimensions of entrepreneurship. En C. A. Kent, D.L. Sexton \& K.H.Vesper (Ed.), The encyclopedia of entrepreneurship. NJ: Prentice Hall.

Smith, B. R., \& Stevens, C. E. (2010). Different types of social entrepreneurship: The role of geography and embeddedness on the measurement and scaling of social value. Entrepreneurship \& Regional Development, 22(6), 575-598. doi:10.1080/08985626.2010.488405

Sociedad Mexicana de Psicología (SMP) (2010). Código ético delpsicólogo. [Ethical code of the Psychologist]. México: Trillas.

Sołtysiak, W. (2014). Entrepreneurship behavior of students and graduates from Jan Długosz University in Czestochowa. Polish Journal of Management Studies, 10(2), 199-208. Retrieved from https://pjms.zim.pcz.pl/resources/html/article/details?id=187737

United Nations Educational, Scientific and Cultural Organization (UNESCO) (2011). [International Standard Classification of Education ISCED 2011]. Canada: Author. Retrieved from http://uis.unesco.org/sites/default/files/documents/international-standard-classification-ofeducation-isced-2011-en.pdf

United Nations Educational, Scientific and Cultural Organization (UNESCO). (2014). UNESCO Operational Strategy on Youth 2014-2021. Paris: Author.

Van de Vijver, F.J.R., \& Tanzer, N.K. (1997). Bias and equivalence in crosscultural assessment: An overview. European Review of Applied Psychology, 47(4), 263-279. doi:10.1016/j.erap.2003.12.004

Velicer, W. F., \& Fava, J. L. (junio, 1998). Affects of variable and subject sampling on factor pattern recovery. Psychological Methods, 3(2), 231. Retrieved from https://psycnet.apa.org/buy/199802615-007

Westlund, H., \& Gawell, M. (2012). Building social capital for social entrepreneurship. Annals of Public and Cooperative Economics, 83(1), 101-116. doi:10.1111/j.1467-8292.2011.00456.x

World Bank (WB) (2017). Social entrepreneurship in Tunisia: achievements and ways forward. Washington, DC.: Author.

World Health Organization (WHO) (2014). Health for the world's adolescents: A second chance in the second decade. Geneva: Author. Retrieved from https://apps.who.int/iris/bitstream/handle/10665/141455/WHO_FWC_MCA_14.05_spa.pd f?sequence $=1$ \&isAllowed $=\mathrm{y}$

World Health Organization (WHO) (2017). Social innovation in healt: Case studies and lessons learned from lowand middle- income countires. Retrieved from https://www.who.int/tdr/publications/year/2017/tdr-sihi-publication-2017.pdf?ua=1 
INTERNATIONAL JOURNAL OF ENTREPRENEURIAL KNOWLEDGE

Issue 1, volume 8, ISSN 2336-2960 (Online)

www.ijek.org

\section{APPENDIX}

\section{Social Entrepreneurial Antecedents Scale}

INSTRUCTION. [INSTRUCCIÓN.] Read each of the following statements and identify (with an X) how well each of them describe you, using the following answer scale: [Lea cada uno de los enunciados e identifique (con una $\mathrm{X}$ ) qué tanto cada uno de ellos lo describe, utilizando la siguiente escala de respuesta:]

Strongly disagree

[Muy en desacuerdo]
2

Disagree

[En desacuerdo]
3

Neither agree nor disagree

[Ni de acuerdo ni en desacuerdo]

\section{4}

Agree

[De acuerdo]
5

Strongly agree [Muy de acuerdo]

1 I have some experience working with social problems. [Tengo alguna experiencia trabajando con problemas sociales.] - - $\quad \begin{array}{lllllll}1 & 2 & 3 & 4 & 5\end{array}$

2 I have volunteered or otherwise worked with social organizations. [He sido voluntario/a o he trabajado con

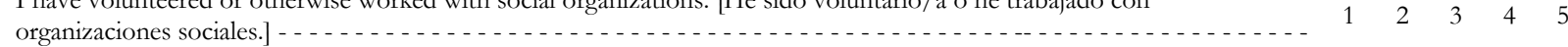

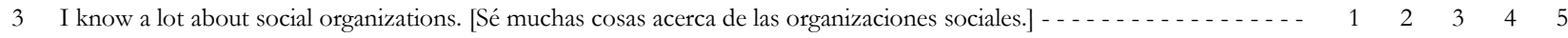

4 I have participated in social groups that are dedicated to solving social problems [He participado en grupos sociales que se

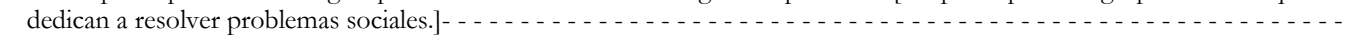

5 I have been involved in projects that have the objective of solving some social problems. [Me he involucrado en proyectos

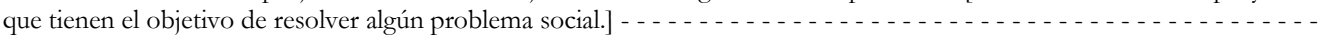

When thinking about socially disadvantaged people, I try to put myself in their shoes. [Cuando pienso en personas con desventaja social, trato de ponerme en sus zapatos.] _ .

7 Seeing socially disadvantaged people triggers an emotional response in me. [Al ver personas desfavorecidas socialmente se desencadena en mí una reacción emocional.] _ . . . . . . . . . . . . . . . . . . . . . . . . . . .

8 I feel compassion for socially marginalized people. [Siento compasión por las personas marginadas socialmente.] - . - . - -

9. It is an ethical responsibility to help people less fortunate than ourselves. [Ayudar a las personas menos afortunadas que nosotros es una responsabilidad social.] _ . . . . . . . .

We are morally obliged to help socially disadvantaged people. [Estamos moralmente obligados a ayudar a personas socialmente desfavorecidas.] - . $\ldots \ldots \ldots \ldots \ldots$

Social justice requires that we help those who are less fortunate than ourselves. [La justicia social requiere que ayudemos a aquellos menos afortunados.] . . . . . . . . . . . . . . . . . . . . . . . . . . . . . . .

It is one of the principles of our society that we should help socially isadvantaged people. [Uno de los principios de nuestra sociedad es que "es nuestro deber ayudar a las personas con desventaja social". . . . . . . . . . . . . . . . . . .

I am convinced that I personally can make a contribution to address societal challenges if I put my mind to it. [Estoy convencido de que personalmente puedo hacer una contribución para lograr cambios sociales, si pongo mi mente en ello.]-

I could figure out a way to help solve the problems that society faces. [Podría imaginar una forma de ayudar a resolver los problemas que enfrenta la sociedad.] - . . . . . . . . . . . . . . . . . . . . . . . . . . . . . .

Solving societal problems is something each of us can contribute to. [Resolver problemas sociales es algo en lo que cada uno de nosotros puede contribuir.] - . . . . . . . . . . . .

People would support me if I wanted to start an organization to help socially marginalized people. [Las personas me apoyarían si quisiera iniciar una organización para ayudar a las personas marginadas socialmente.] - . . . . . . . . . .

17 If I planned to address a significant societal problem people would back me up. [Si planeara hacer frente a un problema

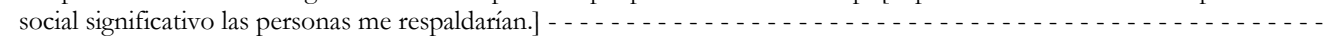

It is possible to attract investors for an organization that wants to solve social problems. [Es posible atraer inversionistas para una organización que quiere resolver problemas sociales.] - . . . . . . . . . . . . . . . .

I expect that at some point in the future I will be involved in launching an organization that aims to solve social problems.

19 [Espero que en algún momento del futuro me encuentre envuelto en la conformación de una organización cuyo objetivo sea resolver problemas sociales.] . . . . . . . . . . . . . . . . . . . . . . . . . . . . . . . .

20 I have a preliminary idea for a social enterprise on which I plan to act in the future. [Tengo una idea preliminar para una empresa social en la que deseo trabajar en el futuro.] . . . . . . . . . . . . . . . . . . . . . . . . . . .

21 I do not plan to start a social enterprise. [No planeo iniciar una empresa social.] -

22 I hope to participate in the creation of a group dedicated to solving social problems. [Espero participar en la creación de

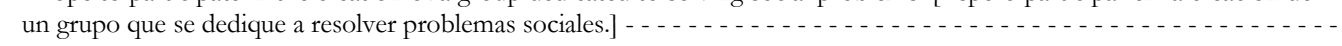
problemas sociales.] . . . . . . . . . . . . . . . . . . . . . . . . . . . . . . . . . 
INTERNATIONAL JOURNAL OF ENTREPRENEURIAL KNOWLEDGE

Issue 1, volume 8, ISSN 2336-2960 (Online)

www.ijek.org

\title{
BRIEF DESCRIPTION OF AUTHOR/AUTHORS:
}

\author{
Authors name and titles: Francisco Quiñonez Tapia (Phd) \\ Department: Department of Public Policies \\ Faculty: Centro Universitario de Ciencias Económico-Administrativas (CUCEA)
}

Affiliation: University of Guadalajara

Address: Periférico Norte $N^{\circ}$ 799, Núcleo Universitario Los Belenes, C.P. 45100, Zapopan, Jalisco, Tel: +52(33) 37703300

Country: Mexico

email address of Author fcoqtapia@yahoo.com.mx

Introduce the Author's position: Professor Researcher

Field of research: Subject and psychology, social psychology and health, native peoples. http://orcid.org/0000-0002-7371-0690

Authors name and titles: Fabiola Gonzalez-Betanzos (Phd)

Department: Methodology,

Faculty: Faculty of Psychology

Affiliation: Michoacan University of San Nicolas de Hidalgo

Address: Francisco Villa 450, Col. Dr. Miguel Silva,Morelia, Mich.

Tel. 31299090 3129913, ext. 127

Country: Mexico

email address of Author. fbetanzos@umich.mx

Introduce the Author's position: Professor Researcher, second author

Field of research: The lines of research that she cultivates are the creation of measuring instruments, data analysis, the development of psychometric and statistical models for the study of school and work trajectories, as well as research in health sciences. https://orcid.org/0000-0003-4585-7211

Authors name and titles: María de Lourdes Vargas-Garduño (Phd)

Department: Social and Educational Psychology

Faculty: Faculty of Psychology

Affiliation: Michoacan University of San Nicolas de Hidalgo

Address: Francisco Villa 450, Col. Dr. Miguel Silva, Morelia, Mich.

Tel. +52(443)3129909 $0+52(443) 3129913$, ext. 124

Country: Mexico

email address of Author. luluvargas61@gmail.com

Introduce the Author's position: Professor Researcher, correspondence author

Field of research: intercultural education, teacher training, academic writing. https://orcid.org/0000$\underline{0002-7384-3098}$

Authors name and titles: Zarina Estela Aguirre Lozano

Department: Department of Social and Legal Sciences

Faculty: Centro Universitario de Ciencias Económico-Administrativas (CUCEA)

Affiliation: University of Guadalajara

Address: Periférico Norte $N^{\circ}$ 799, Núcleo Universitario Los Belenes, C.P. 45100, Zapopan, Jalisco, Tel: +52(33) 37703300

Country: Mexico

email address of Author. zarinaaguirre@gmail.com 
INTERNATIONAL JOURNAL OF ENTREPRENEURIAL KNOWLEDGE Issue 1, volume 8, ISSN 2336-2960 (Online)

www.ijek.org

Introduce the Author's position: Professor Researcher, fourth author

Field of research: intercultural processes, peace management and mediation in the conflict.

http://orcid.org/0000-0002-5334-0688 